\title{
Yuridical Aspect Prevention of "lllegal Fishing" Action in International Law and Implementation in Indonesia
}

\section{Dwi Astuti Palupi}

\section{Abstract}

Fisheries crime, known as Illegal Fishing, is not only carried out by Foreign Fish Ships (KIA) but also by fishermen or Indonesian fishing vessels (KII). According to IPOA, illegal fishing does not only take fish without permits, but also includes unreported fishing, and unregulated fishing;

As an archipelago country that has an interest in the sea, Indonesia nationally adopted UNCLOS III in 1982, with its ratification through Law No. 17 of 1985.

From the above matter, the problem that will be examined is how is the regulation on the prevention of "Illegal Fishing" actions in international law and national law, and how

Received: 18 January 2019

Accepted: 24 March 2019

Published: 31 March 2019

Publishing services provided by Knowledge E

(c) Dwi Astuti Palupi. This article is distributed under the terms of the Creative Commons

Attribution License, which permits unrestricted use and redistribution provided that the original author and source are credited.

Selection and Peer-review under the responsibility of the First ELEHIC Conference Committee. is law enforcement against "lllegal Fishing" actions in Indonesia.

In this study the author uses a type of normative juridical legal research, the data sources used will be more secondary data, although it is not possible to use primary data.

From the results of the study, it can be concluded that, Indonesia was given the authority to capture foreign fishing vessels that committed crimes in the territory of the Republic of Indonesia, namely Article 73 UNCLOS 1982 which states that if foreign ships do not comply with coastal state legislation in terms of fishery resource conservation, the state the beach can catch the ship.

However, the captured vessel and crew must be immediately released with a reasonable bond given to the coastal country. The punishment for the foreign vessel is also not allowed in the form of corporal punishment (prison). This is because in the EEZ, the coastal state only has sovereign rights and not sovereignty.

\section{Background}

NKRI is an archiplelago state, the largest in the world. It is in a cross-country position between two continents and two oceans. As the Indonesian Archipelago consists of many which stretch from Sabang to the West, to the island of Merauke in the East End. 
large (.Tedjo Edhy Purdijatno, Mengawal Perbatasan Negara Maritim, Grasindo, PT. Gramedia Widiasarana Indonesia,2010,HIm.164. Kresno Buntoro, Lintas Navigasi Di Nusantara Indonesia, PT RajaGrafindo Persada, Jakarta,2014, HIm 9.) and small with an estimated sea area of 7.73 million km2 which contains biological and non-biological natural resources. The total area of this territorial waters covers two-thirds of the total area of Indonesia bordering 10 countries.

With such a long coastline, Indonesia's coastal and marine areas are known as the countries with the largest marine wealth and biodiversity in the world by having coastal ecosystems such as mangroves, coral reefs and sea grass beds. (I b i d; The total area of Indonesia is 7.9 million $\mathrm{km} 2$ consisting of 1.8 million $\mathrm{km} 2$ of land, 3.2 million $\mathrm{km} 2$ of territorial sea and 2.9 million $\mathrm{km} 2$ of EEZ waters. The water area of 6.1 million $\mathrm{km} 2$ is $77 \%$ of the total area of Indonesia, in other words Indonesia's sea area is three times the land area; 4.The number of material loss potential due to Illegal Fishing is assumed if the number of foreign and ex-foreign vessels carrying out IUU fishing is around 1000 vessels, fish stolen from IUU fishing activities and discarded by 25\% of stock (FAO estimate, 2001). With this assumption, if MSY (maximum sustainable yield = maximum sustainable catch) of fish $=6.4$ million tons / year, then the lost is stolen and disposed of around 1.6 million tons / year. If the selling price of fish abroad is an average of 2 USD / $\mathrm{kg}$, then the loss per year can reach IDR 30 trillion. By: Mukhtar, A, website of the Ministry of Maritime Affairs and Fisheries.))

Indonesia is like a palace in which treasure is stored, tempting anyone to come to work together to dredge or steal the treasure. One of them stole fish resources contained in this vast sea; known as "illegal fishing".

Juridically Indonesia has ratified UNCLOS III in 1982, as a form of legitimacy in establishing national and state relations, with Law No. 17 of 1985, which had an impact on the increasingly clear boundaries of Indonesian waters with several neighboring countries. This also has the effect of emphasizing that Indonesia has sovereignty in the sea area, including its fishing potential. In addition, the ratification of Indonesia has an impact on Indonesia's obligation to adjust the legislation in Indonesian waters along with the potential contained therein, so a number of laws and regulations such as Law NO. 6 of 1996, Law on Indonesian Waters in lieu of Law NO. 4 / Prp / 1960, Law No. 31 of 2004, which was later replaced by Law No. 45 of 2009, concerning Fisheries, and Law no. 32 of 2014 concerning Marine Affairs Marine. 


\section{Identification of Problems}

1. Rules for Prevention of "Illegal Fishing" Measures in International Law.

2. Law Enforcement of "lllegal Fishing" actions in Indonesia.

\section{Discussion}

\subsection{Some rules for the prevention of "llegal fishing" actions according to international law}

In terms of illegal fishing, the meaning is literally derived from English, which consists of two words of illegal and fishing. "Illegal" means illegal, prohibited or contrary to law. "Fish" means fish or meat and "fishing" means fishing as a livelihood or a place to catch fish. (Purwadarminta, Kamus Besar Bahasa Indonesia.) Based on the meaning above, illegal fishing means fishing or illegal fishing activities.

So illegal fishing is fishing that is done by violating the laws that have been established in the waters of a country. The definition of illegal fishing is usually in tandem with the notion of unregulated and unreported fishing, making it difficult for local authorities to monitor the resources that have been exploited.

There are several factors that cause Illegal fishing in Indonesian waters can not be separated from the condition of fisheries in other countries that have sea borders, and fisheries management systems in Indonesia itself. Factors causing illegal fishing can be categorized into 7 (seven) factors, as described below; (http://mukhtar-api.blogspot.co. id/2011/05/illegal-fishing-di-indonesia.htm)

First, the world fish demand (demand) increases, on the other hand the world fish supply decreases, there is overdemand especially types of fish from the sea such as tuna. This encourages the world fishing fleet to hunt fish anywhere in a legal or illegal way.

Second, the disparity (difference) in the price of whole fish in other countries compared to Indonesia is high enough to make a surplus of income.

Third, fishing ground in other countries has begun to run out, while in Indonesia it is still promising, even though they have to maintain the supply of fish for their consumption and must maintain processing production in the country still survive.

Fourth, the Indonesian Sea is very broad and open, on the other hand the supervision capability, especially the national surveillance fleet (supervisory vessel) is still very limited compared to the need to monitor vulnerable areas. 
Sixth, there are still limited facilities and infrastructure for supervision and human resource supervision, especially in terms of quantity.

Seventh, the perception and cooperation steps of law enforcement officers are still in handling cases of criminal acts of fisheries are still not solid, especially in terms of understanding legal actions, and the commitment of the operations of the supervisory vessel at EEZ.

\subsubsection{Prevention rules for "Illegal fishing" measures in international law}

The Ministry of Maritime Affairs and Fisheries of the Republic of Indonesia, limits the term Illegal fishing as an understanding which includes "illegal, unreported and unregulated (IUU) fishing which can literally be interpreted as illegal fishing activities, which are not regulated by existing regulations, and which not reported to an available fisheries management institution or institution.

This refers to the understanding issued by the illegal, unreported, unregulated (IUU) International Plan of Action (IPOA) initiated by FAO in the context of implementing the Code of Conduct for Responsible Fisheries (CCRF). Illegal fishing is related in 4 respects, namely Understanding Illegal Fishing is explained as follows; (Departemen Kehutanan dan Perikanan Indonesia, Nasional Plan of Action of Indonesia To Prevent, Deter and Elininate Illegal, Unreported and Unregulated Fishing, ( Jakarta, 2004), hal. 6-7. Universitas Sumatera Utara $\mathrm{xxxi)}$

1. Fishing activities carried out by a particular country or foreign vessels in waters that are not their jurisdiction without permission from countries that have jurisdiction or fishing activities contrary to state laws and regulations.

2. Fishing activities carried out by flagged fishing vessels one of the countries that joined as a member of the management organization regional fisheries.

3. Fishing activities that are contrary to the legislation a country or international provisions.

So, Illegal Fishing, in an international definition, is a fishery crime not only fishing (illegal fishing), but also unreported fishing, and unregulated fishing. Countries that have not reported their fisheries status clearly can be categorized as having committed crimes. The right thing to do now is to report according to accurate data so that the international community can help Indonesia through appropriate action.

There are several provisions in international law which regulate the prevention of "Illegal Fishing" actions: 
1. The 1982 United Nations Convention on the Law of the Sea (hereinafter referred to as UNCLOS III / 1982) does not regulate Illegal, Unreported and Unregulated Fishing (IUU Fishing), however, it regulates in general the law enforcement in the territorial sea and EEZ of a country, that is, if there is a violation of the legislation of the coastal state occurring in the territorial sea or inland waters of a country, then in accordance with the sovereignty granted by Article 2 of UNCLOS 1982; the coastal state can impose its legal rules and even criminal law on the vessel only if the violation has an impact on the coastal state or disturbs the security of the coastal state.

The enactment of the provisions of Article 2 of UNCLOS III 1982 is closely related to the sound of Article 27 paragraph 1; that is, if the elements mentioned in Article 27 paragraph 1 of UNCLOS 1982 were not fulfilled, then the coastal state could not apply its criminal jurisdiction to the vessel.

Article 27 Paragraph 5 of UNCLOS III / 1982 then refers to Chapter V regarding EEZ in the event of violations of coastal state legislation relating to the exploration and exploitation of fisheries resources. This is different if violations occur in the EEZ, especially violations of the exploration and exploitation of fisheries resources.

Furthermore, in Article 73 of UNCLOS III / 1982, it is stated that if foreign ships do not comply with the laws of the coastal state in terms of conservation of fishery resources, the coastal state can arrest the vessel.

However, the captured vessel and crew must be immediately released with a reasonable bond given to the coastal country. And the sentence imposed on the foreign vessel is also not allowed in the form of a body punishment, namely prison. This is because in the EEZ, the coastal state only has sovereign rights and not sovereignty.

\section{Code of Conduct for Responsible Fisheries (CCRF)}

The CCRF was one of the agreements at the FAO's 28th Committee on Fisheries (COFI) in Rome on October 31, 1995, which was stated in resolution No. 4/1995 which officially adopted the document of the Code of Conduct for Responsible Fisheries.

This Code of Conduct has become an international principle and standard regarding responsible behavior patterns, in managing fisheries resources with the aim of ensuring the effective aspects of conservation, management and development of aquatic biological resources in relation to ecosystem and biodiversity conservation, and are voluntary. based on relevant international law, 
CCRF, applied globally, as a non-binding instrument for responsible fisheries. According to the CCRF, countries and all parties involved in fisheries management must adopt long-term conservation measures and use sustainable fisheries resources.

Conservation and management measures, both at the local, national, subregional or regional levels, must be based on the best available scientific evidence and designed to ensure long-term sustainability of fisheries resources at a level that can support the achievement of the objectives of optimum utilization and maintain availability for current and future generations.

In the implementation of the CCRF, countries must ensure the establishment of an effective legal and administrative framework both at the regional and national / central levels for the conservation of fish resources and fisheries management. (Marhaeni Ria Simbolon, Hukum Perikanan Nasional dan Internasoinal (Dalam Kerangka Pengelolaan Perikanan Yang Berkelanjutan), Gramedia Pustaka Utama, Jakarta, HIm.65)

In addition, the state in accordance with its laws and regulations must implement monitoring, control and surveillance measures as well as effective law enforcement or guarantee legislation that contains sanctions that are commensurate with the severity of the violation, if need to include implementing.

In addition, the state in accordance with its laws and regulations must implement monitoring, control and surveillance measures as well as effective law enforcement or guarantee legislation that contains sanctions that are commensurate with the severity of the violation, if need to include carrying out observer programs (observer programs), inspection schemes and Vessel monitoring systems.

3. International Plan of Action to Prevent, Deter and Eliminate IIlegal, Unreported, Unregulated Fishing 2001 (IPOA-IUU Fishing).

In this case, FAO member countries have formulated and agreed on international action (International Plan) to combat IUU Fishing, which was then outlined in the IUUFishing International Plan of Action to Prevent, Determine and Eliminate (IPOAIUU Fishing) in 2001.

IPOA-IUU Fishing is a global action plan in order to prevent damage to fishery resources and rebuild fishery resources that have been or are almost extinct. IPOAIUUFishing is voluntary and is the implementation of CCRF.

The preparation of this guideline aims to prevent, inhibit and eliminate illegal fishing activities by preparing comprehensive, integrated, effective and transparent 
measures of fish resources management by taking into account its sustainability for all countries in the world.

Thus IPOA-IUU Fishing is a guideline that contains programs that can be used by the state to combat IUUFishing activities.

According to IPOA-IUU Fishing, countries must pay attention to their respective national legislation which contains effective rules for all aspects. Countries must ensure that harsh sanctions against IUU Fishing vessels in their jurisdiction can effectively prevent, reduce and eliminate IUUFishing, and prevent perpetrators from benefiting from the region.

The IPOA-IUUFishing must be followed up by each country by developing and implementing it into a national action plan. (Maimuna Renhoran, 2012, Strategi Penanganan Illegal, Unreported and Unregulated (IUU) Fishing di Laut Arafura, Tesis Fakultas Hukum Universitas Indonesia, Jakarta, (selanjutnya disingkat Maimuna Renhoran I), h. 19) IPOA-IUUFishing follow-up for Indonesia with the issuance of the Decree of the Minister of Maritime Affairs and Fisheries No. KEP / 50 / MEN / 2012.

4. Regional Plan of Action to Promote Responsible Fishing Practices including Combating IIlegal, Unreported and Unregulated (IUU) Fishing in the Region 2007.

Regional Plans of Action to Promote Responsible Fishing Practices including Combating Illegal, Unreported and Unregulated (IUU) Fishing in the Region (hereinafter referred to as RPOA) aims to promote responsible fishing activities including eradication of IUU Fishing in the region.

RPOA was ratified in Bali-Indonesia on 4 May 2007 by 11 Ministers responsible for fisheries from 11 countries as regional commitments. RPOA is a joint initiative between the government of the Republic of Indonesia and the Australian government in combating IUU Fishing activities.

At the first RPOA Meeting, in Manila-Philippines, April 28-30, 2008, it was agreed that the Committee would be asked to periodically report to the Minister of Fisheries about the progress of implementation and additional steps needed for the implementation of the RPOA. 


\subsection{Law enforcement "Illegal fishing" in Indonesia according to Law No. 31 of 2004 concerning fisheries}

As a follow-up to the obligation of ratification in the field of fisheries and maritime Indonesia has had Law 31 of 2004, amended by Law 45 of 2009, and Law 34 of 2014 concerning marine affairs.

"Illegal fishing" is most common in the Indonesian fisheries management area (WPP), not only is the theft of fish carried out by foreign fishing vessels originating from neighboring countries, it is also very often carried out by fishing vessels that Indonesian flag.

Although it is difficult to map the level of illegal fishing that occurs in WPP-RI, it can be concluded that illegal fishing by Foreign Fish Ships occurs mostly in ZEE (Exlusive Economic Zone) and also occurs quite a lot in Archipelagic State. WPP referred to here is the waters of Indonesia including (Inland Water and Internal Water), and EEZ.

In general, the types of fishing equipment used by foreign fishing vessels or illegal exforeign vessels in Indonesian waters are productive fishing tools such as purse seines and trawling. It is also known that illegal fishing is also often carried out by Indonesian fishing vessels (KII).

Several modes / types of illegal activities that are often carried out by KII include:

1. Fishing without permits (Fisheries Business License (SIUP) and Fishing Permit (SIPI) or Fish Transport Ships Permit (SIKPI))

2. Having permits but violating the stipulated provisions (violation of fishing grounds, fishing gear violations, breach of obedience based), falsification / manipulation of documents (procurement, registration and licensing documents), transshipment at sea, not activating transmitters (specifically for ships who are required to install the transmitter), and

3. Catching fish that destroy (destructive fishing) by using chemicals, biological materials, explosives, tools and / or ways, and / or buildings that endanger preserving fish resources.

In connection with the Law Enforcement of Illegal Fishing in WPP, UNCLOS III / 1982 divided the sea area into three parts, namely:

1. the territory which is the sovereignty of the state, namely the sea area where the state has full authority and can enforce its national law; (Internal Water, Archipelagic Water and Territorial Sea). 
2. the sea area which is the state's jurisdiction, namely the sea area which is only an authority in certain matters; (Contiguous Zone, Economic Exclusive Zone)

3. sea areas that do not become state jurisdictions; (High Seas).

Article 73 of UNCLOS III / 1982, stipulates that:

1. Coastal States can, in exercising their sovereign rights to carry out exploration, exploitation, conservation and management of biological resources in the economic zone, take such actions, including boarding ships, inspecting, arresting and carrying out court proceedings, as necessary to ensure compliance with laws and regulations. invitations stipulated in accordance with the provisions of this Convention.

2. The captured vessels and their crew must be released immediately after being given a proper security deposit or other form of guarantee.

3. Coastal state penalties imposed for violations of fisheries laws and regulations in exclusive economic zones may not include confinement, if there is no reverse agreement between the countries concerned, or any other form of corporate punishment.

4. In the case of the capture or detention of foreign ships, the coastal state must immediately notify the flag state of the ship through the appropriate channels, regarding the actions taken and regarding any penalties that are subsequently dropped.

Pursuant to Article 73 of UNCLOS III in 1982, if foreign ships do not comply with the legislation of coastal state fisheries at EEZ, the coastal state can board, inspect, capture and conduct court proceedings on the vessel and notify the flag state.

However, the captured vessel and crew must be immediately released with a reasonable security deposit given to the coastal state. Penalties imposed cannot be in the form of corporal or prison sentences.

If the foreign vessel refuses to be inspected and even runs away, the fisheries investigator can conduct a Right of hot pursuit. Immediate pursuit of a foreign vessel is carried out if the fisheries investigator has sufficient reason to suspect that the vessel is illegal or has violated national legislation. Pursuit can be carried out until the EEZ and stop after the chased vessel enters its own territorial sea or third country EEZ.

In practice the involvement of foreign parties in the theft of fish can be classified into two, namely as follows: (http://mukhtar-api.blogspot.co.id/2013/07/aspek-hukumpenanganan-tindak-pidana.html) 
First, semi-legal theft, namely the theft of fish carried out by foreign vessels by utilizing legal fishing licenses owned by local businessmen, using local flagged vessels or other countries' flags. This practice is still categorized as illegal fishing because in addition to catching fish in the territorial waters which are not their rights, these illegal fishing actors also often send the catch directly without going through the process of landing fish in a legitimate area. This practice is often referred to as the Flag of Convenience (FOC) practice.

Second, is pure illegal theft, namely the process of fishing carried out by foreign fishermen and the foreign vessel uses its own flag to catch fish in our area. This activity is quite a large number, based on FAO estimates (2008) there are around 1 million tons per year with the number of ships around 3000 ships. The ships are from Thailand, Vietnam, Malaysia, China, Philippines, Taiwan, South Korea and others.

Illegal fishing practices are not only carried out by foreign parties, but also by local fishermen / entrepreneurs. Illegal fishing practices carried out by local fishermen / entrepreneurs can be classified into 3 (three) categories, namely: (Ibid.)

1. Indonesian-flagged fishing vessels used by foreign fishing vessels whose documents are fake or do not even have a permit document;

2. Indonesian Fishing Vessels (KII) with asphalt or "original but fake" documents (officials who issue non-authorized, or fake documents);

3. Indonesian fishing boats without any documents at all means fishing without permission.

Illegal Fishing activities at WPP-RI have resulted in huge losses for Indonesia. Overfising, overcapacity, threats to the sustainability of fish resources, a non-conducive fishery business climate, weakening of the competitiveness of companies and the marginalization of fishermen is a real impact of IUU fishing activities.

Law Number 45 of 2009 concerning Fisheries states that fishing is an activity to obtain fish in waters that are not cultivated by means or by any means, including activities that use ships to load, transport, store, cool, handle, process, and / or preserve it.

Illegal fishing means all forms of fishing activities that violate Law No. 31 of 2004 concerning Fisheries Jo. Law Number 45 of 2009 and other applicable laws and regulations.

Furthermore, Article 5 of Law No. 31 of 2004 states that the Republic of Indonesia Fisheries Management Area (WPP) allowed for fishing and / or fish cultivation includes (1); a. Indonesian waters; (Inland waters, island waters and territorial sea); b. ZEEl;c. Rivers, lakes, reservoirs, swamps, and other puddles that can cultivated as well as potential 
fish farming land in territory of the Republic of Indonesia, held based onlegislation, requirements, and / or standards internationally accepted in general Paragraph (2).

Everyone who carries out fisheries management business and / or activities must comply with what is stipulated by the Minister, Article 7 paragraph (1) of Law 31 of 2004, concerning: a. the type, amount and size of fishing gear; b.type, number, size and placement of fishing aids; $c$. area, path, and time or season of fishing; $d$. requirements or standard operating procedures for fishing; e. fishing vessel monitoring system;f. new types of fish that will be cultivated; g. types of fish and re-distribution areas and cultivationbased fishing; $h$. fish cultivation and protection;i. prevention of pollution and damage to fish resources and the environment; $j$. the size or weight of the type of fish that can be caught; k. fishing sanctuary;l. outbreaks and areas of fish disease outbreaks; $m$. types of fish that are prohibited from being traded, included, and issued to and from the territory of the Republic of Indonesia; and n. protected fish species, Paragraph (2).

Every person is also prohibited from fishing and / or fish cultivation using chemicals, biological materials, explosives, tools and / or methods, and / or buildings that can harm and / or endanger the sustainability of fish resources and / or the environment in the region. Republic of Indonesia fisheries management. Article 8 paragraph (1) Law No. 31 of 2004.

Then, Article 9 prohibits anyone from possessing, controlling, carrying, and / or using on fishing vessels in the Republic of Indonesia fisheries management area: a. Fishing equipment and / or fishing devices that do not in accordance with the specified size; b. Fishing equipment that is not in accordance with requirements or standards specified for certain types of tools; and / or c. Fishing equipment that is prohibited.

Article 26 and Article 27, determine that every person who conducts a fishery business, is obliged to have an SIUP, SIPI, SIKPI, issued by the Minister. Except against a person or a foreign legal entity conducting fishing business in ZEEl, insofar as it concerns the obligation of the Republic of Indonesia based on international agreements or the applicable rules of international law. Government of the flag state must include flag state government's obligation to be responsible for the compliance person or legal entity to comply with the flag state of the fishing agreement. Paragraph (4).

Provisions for Foreign Fish Vessels carrying out fishing are as follows: a. If you do not have a fishing license as long as you are in the territory of the Republic of Indonesia fisheries management, you must keep fishing gear in the hold. b. Article 38 paragraph (1). If you have had a fishing license with 1 (one) type of fishing gear in certain parts of the ZEEI, it is prohibited to bring other fishing gear, paragraph 2 , and must keep fishing 
equipment in the hold while outside the fishing area permitted in Republic of Indonesia fisheries management area. Paragraph 3.

Article 39 of Law 31 of 2004, for Indonesian-size fishing vessels of a certain size and type, it is possible to use 2 (two) types of fishing gear that are permitted alternately based on season and area of fishing operations.

In connection with criminal acts Illegal fishing Law 31 of 2004 has arranged for ships that:

1. Not having SIUP, subject to Article 26 paragraph (1) in conjunction with Article 92 of the Republic of Indonesia Law No. 31 of 2004 concerning Fisheries, sentenced to a maximum of 8 (eight) years imprisonment and a maximum fine of Rp. $1,500,000,000$ (one billion five hundred million rupiah).

2. Fishing gear not in accordance with the size, can be subject to Article 85 UUP with a maximum penalty of 5 (five) years and a fine of at most Rp. 2,000,000,000 (two billion rupiah)

3. Do not have a Sailing License, subject to Article 98 of the Fisheries Law with a maximum jail sentence of 1 (one) year and a maximum fine of Rp. 200,000,000 (two hundred million rupiah).

\section{Conclusion}

Fish theft crimes committed in areas that are subject to a country's jurisdiction, in international law, are included in the sense of IUU Fishing, as agreed in the IPOA.

Article 2 of UNCLOS III / 1982, Coastal States can impose criminal law on foreign ships if the violation impacts the coastal state or disturbs the security of coastal countries. However, if the elements mentioned in Article 27 paragraph 1 of UNCLOS 1982 were not fulfilled, the coastal state could not apply its criminal jurisdiction to the vessel, namely a violation of the coastal state legislation relating to the exploration and exploitation of fishery resources.

Article 73 of UNCLOS 1982 stated that if a foreign vessel does not comply with the legislation of the coastal state in terms of conservation of fishery resources, the coastal state can arrest the vessel. However, the captured vessel and crew must be immediately released with a reasonable bond given to the coastal country. Punishment for foreign ships is also not allowed in the form of corporal punishment, namely prison. This is because in the $\mathrm{EEZ}$, the coastal state only has sovereign rights and not sovereignty. 
Related to the follow-up of Indonesia's participation, IPOA-IUUFishing; each country can develop and implement it into a national action plan. for Indonesia has issued the Decree of the Minister of Maritime Affairs and Fisheries No. KEP / 50 / MEN / 2012. For Indonesian Fish vessels that carry out Illegal Fishing activities, are subject to Act No. 31 of 2004: a). Not having SIUP, subject to Article 26 paragraph (1) in conjunction with Article 92 of the Republic of Indonesia Law No. 31 of 2004.b). Fishing gear not in accordance with the size, can be subject to Article 85 UUP.c). Do not have a Sailing License, subject to Article 98 of the Fisheries Law.

\section{References}

[1] Buntoro, Kresno.2014. Cross Navigation in Nusantara Indonesia, Jakarta, PT. RajaGrafindo.

[2] Maimuna Renhoran, 2012, Strategy for Handling Illegal, Unreported and Unregulated (IUU) Fishing in the Arafura Sea, Thesis Faculty of Law, University of Indonesia, Jakarta,

[3] Purdijatno, Tedjo Edhy. 2010. Escorting the Maritime State Border, Jakarta. PT. Gramedia Widiasarana Indonesia.

[4] Siombo, Marhaeni Ria.2010 National and International Fisheries Law, Jakata. PT Gramedia Pustaka Utama.

[5] Supriadi, 2011. Fisheries Law in Indonesia, Jakata. Sinar Grafika, Purwadarminta, Big Indonesian Dictionary.

[6] Indonesian Ministry of Forestry and Fisheries, 2004. National Plan of Action of Indonesia to Prevent, Detain and Eliminate Illegal, Unreported and Unregulated Fishing, Jakarta, UNCLOS III in 1982.

[7] Law 31 of 2004 concerning Fisheries Jo. Law 45 of 2009.

[8] Law 34 of 2014 concerning Marine Affairs.

[9] http://mukhtar-api.blogspot.co.id/2013/07/aspek-hukum-penanganan-tidak-pidana. html

[10] http://mukhtar-api.blogspot.co.id/2011/05/illegal-fishing-di-indonesia.html 